\title{
Analysis Of Accounting Information System In Merchantability Inventory With Fifo And Average Method At Pt. Main Dennis
}

\author{
Dwi Kartinah \\ Faculty of Computer Science and Information Technology, Gunadarma University, Indonesia \\ * Corresponding author: \\ Email: dwi kartinah@staff.gunadarma.ac.id
}

\begin{abstract}
.
The author chose PT Dennis Utama as the object of research. PT Dennis Utama is a company that distributes food ingredients, namely rice. Researchers obtained primary data from interviews by the sales department of PT Dennis Utama and secondary data from literature studies using flowchart and descriptive analysis techniques. The analysis used is the FIFO and AVERAGE methods. The aim is to find out the results of the analysis of the merchandise inventory accounting information system at PT Dennis Utama with the FIFO and AVERAGE methods. The results of this study are in the form of flowcharts and descriptive results. Based on the results of the research that PT Dennis Utama uses the FIFO and AVERAGE methods which are quite good, there are only a few shortcomings, namely sometimes there is still a little buildup of goods so that merchandise is damaged and also the company has not implemented a computerized system in its company activities.
\end{abstract}

Keywords: Merchandise Inventory, FIFO, AVERAGE, PT Dennis Utama

\section{INTRODUCTION}

At this time the development of the business world is growing and developing rapidly, causing increasingly fierce competition. Every entrepreneur must have their own sales strategy that aims to increase their sales. However, to increase sales not only from strategy but from the way of managing and recording merchandise is also very important. Mastering how to buy, sell and record merchandise is very important for every entrepreneur to avoid mistakes.By mastering the method or strategy of buying, selling and recording merchandise inventory, entrepreneurs know which merchandise inventory to sell first. Merchandise inventory that is sold first is usually the inventory of merchandise that enters (purchased) the first time or enters the warehouse earlier.

So it can be seen from the time the merchandise entered the warehouse and can also be called when the merchandise was purchased. From there, entrepreneurs can distinguish which merchandise inventory will be sold first and which will be sold later. Inventory of merchandise that is stored properly will make the inventory of merchandise protected from damage.If an error occurs in the purchase, sale and recording of merchandise, it will cause significant problems for entrepreneurs because it will cause huge losses. One way to avoid problems in the inventory of merchandise is to use an accounting information system. Inventory of merchandise must be recorded properly and accurately so as to avoid mistakes.Like the FIFO (First In First Out) method, the FIFO method is a method where the first item that enters means that the item is the first one out. Under the FIFO method, the cost of inventory is calculated based on the assumption that the goods will be sold or used alone and the remaining in inventory represents the last purchase or production.

\section{LITERATURE REVIEW}

\section{System Definition}

The system is a series of two or more components that are interrelated and interact to achieve a goal (Romney, 2015: 2).The system is a group of elements that are closely related to one another, so that with these systems and procedures the company's goals are achieved (Mulyadi, 2008). The system is a network of procedures that are interconnected, gathered together to perform an activity or complete a specific target (Jogiyantoo, 2005).The system is a set of elements that form a collection or procedures/processing charts that seek a common goal or purpose by operating data and/or goods at certain reference times to produce 
information and/or energy and/or goods (Murdick, RG , 1991: 27). The system is a network of procedures that are interconnected, gathered together to perform an activity or to complete a certain goal (Jerry FutzGerald, 1981: 5).

\section{Understanding Information}

Information is data that has been processed into a form that is meaningful to the recipient and useful for current or future decision making (Gordon B. Davis, 1991: 28).Information is data that is presented in the form of a form. The data has uses in making or making decisions (Gelinas \& Dull, 2012).Information is data that has been organized and has had uses and benefits (Krismaji, 2015: 14).Information is data that is processed so that it can be used as a basis for making the right decisions (George H. Bodnar, 2000: 1). Information is data that has been managed and processed to provide meaning and improve the decisionmaking process. As its role, users make better decisions as the quantity and quality of information increase (Romney and Steinbart, 2015: 4).

\section{METHODS}

\section{Flow chart}

Flowchart is an analytical technique used to explain aspects of information systems clearly, precisely and logically (Krismaji, 2010).Flowcharts use diagrams of standard symbols that show the flow of data to describe through pictures of the transaction processing stage procedures used by the company and the flow of data through the system.Standard symbols in document flowcharts have special meanings that are easily discernible from their shape. The form of these symbols shows and describes the process carried out and the input, output, processing and storage media used.This symbol can be used in companies that do not yet have an accounting system in the form of a flowchart, so the purpose of using a flowchart is to manage all operational activities and provide convenience in managing the flow of raw material inventory that remains on their respective tasks. part by not leaving the company flow.

\section{Internal Control System}

According to Diana and Setiawati (2011: 82) internal control is all organizational plans, methods and measurements chosen by a business activity to secure its assets, check the accuracy and reliability of the business's accounting data, improve operational efficiency and support the compliance of established managerial policies. . This internal control is important because the company likes or dislikes facing many threats that can interfere with the achievement of the company's accounting information system goals.

According to Jones (2008: 132) internal control is a process, which is influenced by the board of directors, entities, management, and other personnel, which is designed to provide reasonable assurance regarding the achievement of category goals including operating effectiveness and efficiency, reliability of financial reporting and compliance with applicable laws and regulations.

Meanwhile, according to Krismiaji (2015: 216) internal control is an organizational plan and method used to maintain or protect assets, produce accurate and reliable information, improve efficiency and to encourage compliance with management policies.According to Diana and Setiawati (2011: 82) COSO defines internal control as a process implemented by the board of directors, management, and all staff and employees under their direction with the aim of providing adequate guarantees for achieving control objectives. The control objectives include the effectiveness and efficiency of operations, reliability of financial reporting as well as compliance with existing rules and regulations.

According to Romney and Steinbart (2015: 227) internal control performs three important functions as follows:

\section{Preventive Control}

Preventive controls are controls that prevent problems before they arise. Examples: recruiting qualified personnel, segregating employee duties and controlling physical access to assets and information.

\section{Detective Control}

Detective controls are controls that spot unavoidable problems. Example: duplicating checking calculations and preparing bank reconciliations and monthly trial balances. 


\section{Corrective Control}

Corrective controls are controls that identify and correct problems and correct and recover from the resulting errors. Example: recollection of transactions for further processing.

\section{RESULTS AND DISCUSSIONS}

Proposed Information System for Sales of Merchandise Inventory of PT Dennis Utama Based on the flow of the merchandise inventory sales system of PT Dennis Utama, the author proposes to carry out computerized sales activities using Zahir Interprise 6. Then the proposed flow of the PT Dennis Utama merchandise inventory sales system is as follows:

\section{Salesman}
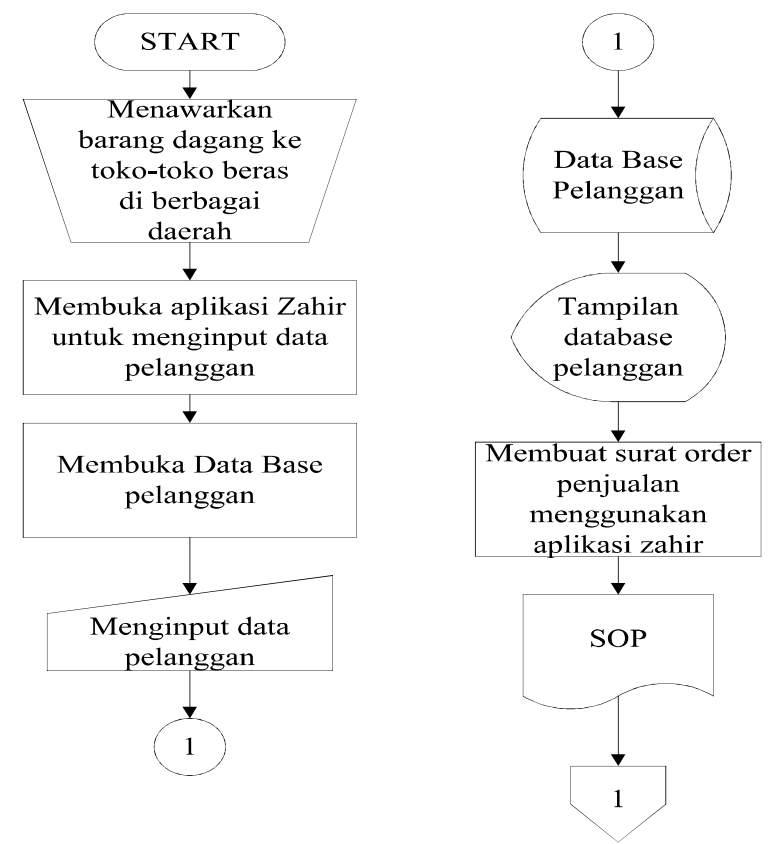

\section{Marketing Section}

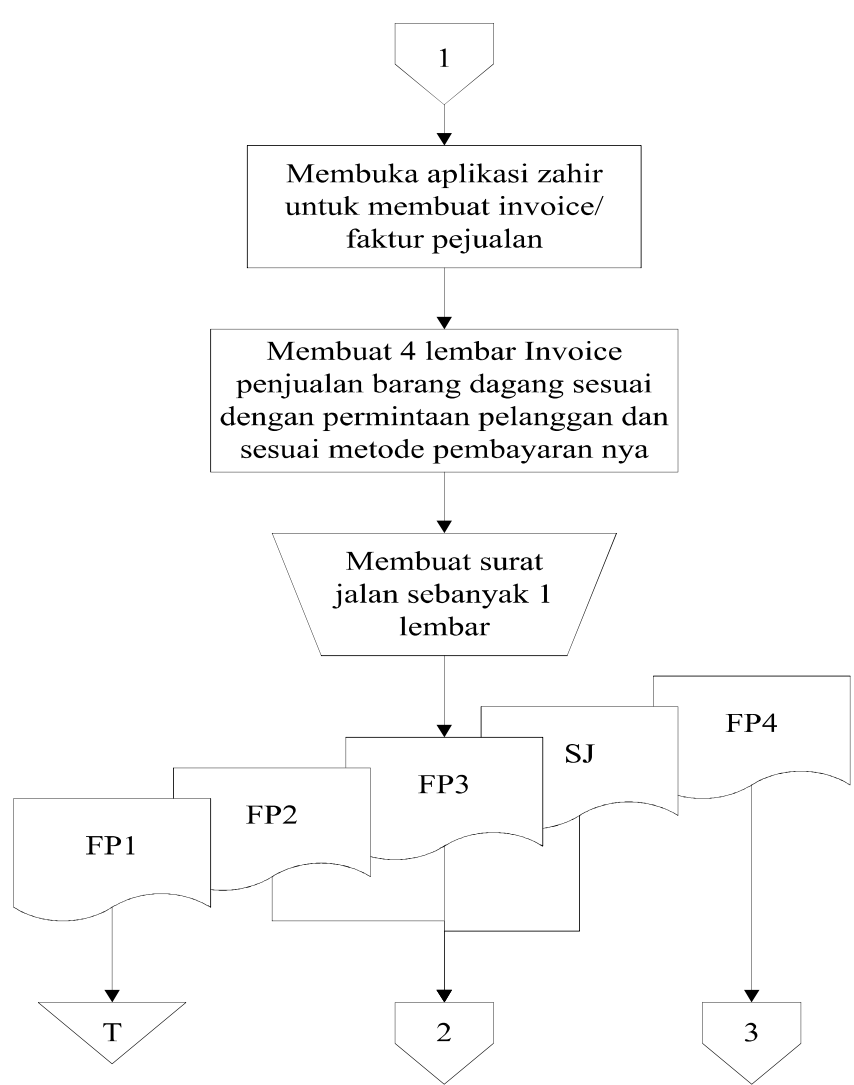




\section{warehouse section}

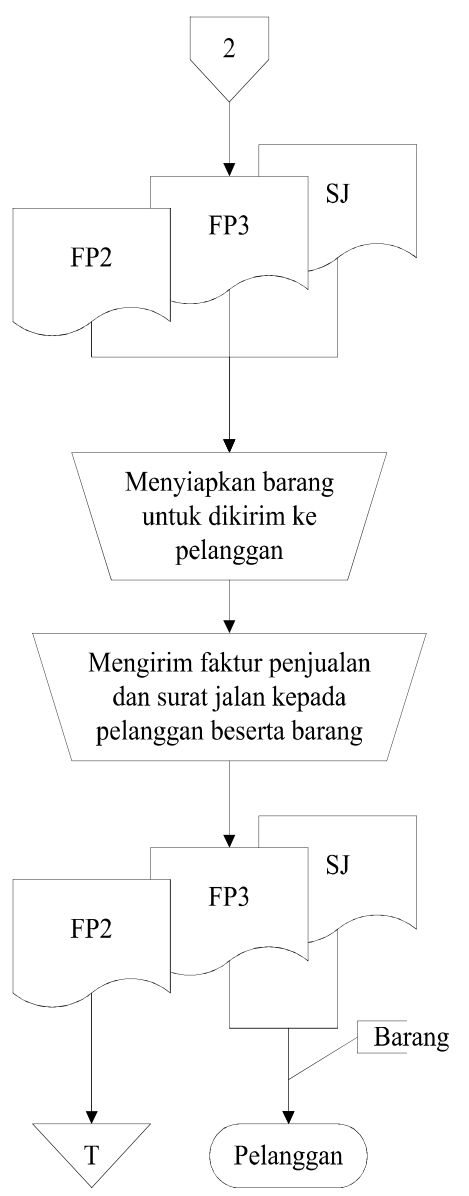

\section{Financial Departement}

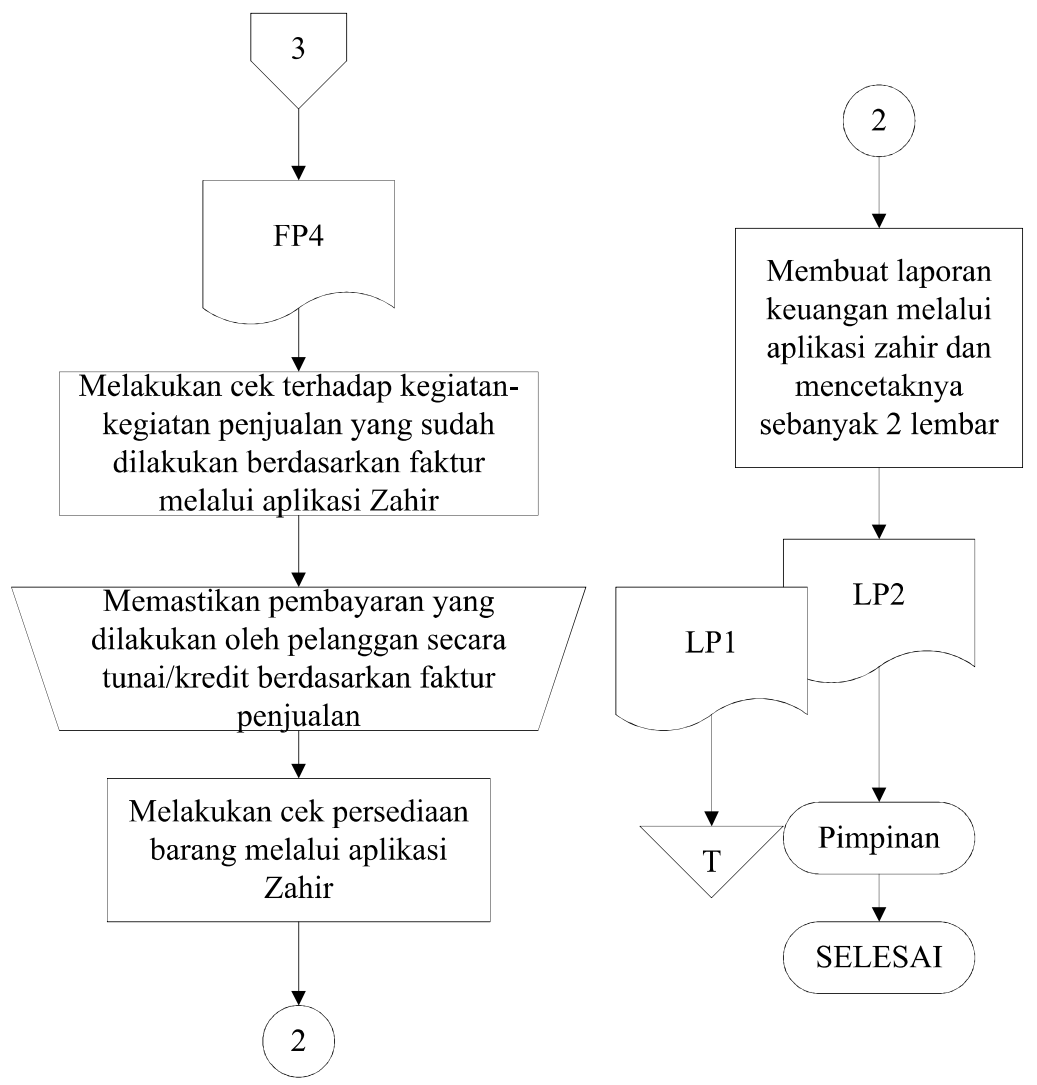




\section{CONSLUSION}

Based on the results of research on the analysis of accounting information systems for merchandise inventory using the fifo and average methods at PT Dennis Utama, the conclusions generated are as follows:

1. The accounting information system for merchandise inventory at PT Dennis Utama has not been effective and efficient because it has not been computerized, all activities are still carried out manually. This can be seen from the record of merchandise inventory written in the book and evidence of sales still using paper invoices.

2. The merchandise inventory accounting information system at PT Dennis Utama is in accordance with the FIFO method. This can be seen from the first incoming goods to PT Dennis Utama, the first incoming goods will be sold first according to the time of entry. Although sometimes there is a buildup of goods so that merchandise is damaged, the application of this FIFO method at PT Dennis Utama is quite good. The merchandise inventory accounting information system at PT Dennis Utama is in accordance with the AVERAGE method. This can be seen from dividing the cost of merchandise available for sale in each type based on its weight $(\mathrm{kg})$ with the number of units based on each type (in $\mathrm{kg}$ ) available.

\section{SUGGESTIONS}

The suggestions that the author can convey for the merchandise inventory accounting information system at PT Dennis Utama are as follows:

1. We recommend that the accounts receivable section be eliminated because according to the author it is less efficient. The work in the accounts receivable section should be included in the sales department, because it only makes an order note.

2. Immediately carry out activities to teach employees to use computers in company activities so that company activities become computerized. Then by using the Zahir Enterprise 6 assistant application, the company's activities will be more organized and the division of tasks for each section will be clearer. The financial reports that will be provided to the company's leadership will also be of higher quality.

\section{REFERENCES}

[1] Mardiani, Eri, et al. 2017. Membuat Aplikasi Penjualan Menggunakan Java Netbeans, MySQL, dan iReport. Elex Media Komputindo.

[2] Dhika, Harry, Nasrulloh Isnain, and Muhammad Tofan. 2019. Manajemen Villa Menggunakan Java Netbeans Dan Mysql. IKRA-ITH INFORMATIKA: Jurnal Komputer Dan Informatika 3.2 (2019): 104-110.

[3] Nur, Hidayati. 2019. "Penggunaan Metode Waterfall Dalam Rancang Bangun Sistem Informasi Penjualan." Generation Journal 3.1 (2019): 1-10.

[4] Maulana, Imam Fadhilah, Siti Khotijah, and Ambar Tri Hapsari. 2020. "Perancangan Sistem Informasi Kasir Di I-Wash Cuci Kendaraan Berbasis Java Netbeans." Journal of Information System, Informatics and Computing 4.2 (2020): 111-117.

[5] Pratiwi, Adha Rusdita, Puji Astuti, and Endang Sulistyaniningsih. 2021. "Aplikasi Penjualan Dan Pemesanan Pada Cipta Rasa Bakery Berbasis Java Netbeans." Semnas Ristek (Seminar Nasional Riset dan Inovasi Teknologi). Vol. 5. No. 1. 2021.

[6] Anastasya, Falya, Irwan Agus, and Bertha Meyke W. Hutajulu. 2021. "Perancangan Aplikasi Penjualan, Pembelian Pada Toko Nodent Store Berbasis Java Netbeans Di Buaran Jakarta Timur." Jurnal Sistem Informasi, Teknologi Informasi dan Komputer 11.2 (2021): 50-55.

[7] Ali, Alfajri. 2019. "Rancang Bangun Aplikasi Penjualan Barang Berbasis Java Programming." Simtika 2.1 (2019): 8-17.

[8] Yurinda, Rizka. 2016. Pembuatan Aplikasi Kasir Minimarket Menggunakan Visual Basic.NET dan MYSQL. Jakarta : Universitas Gunadarma.

[9] Puspita, Ari, Ade Fitria Lestari, and Hilda Amalia. 2019. "Sistem Informasi Penjualan Sparepart Mobil Menggunakan Aplikasi Java Berbasis Unified Modeling Languange (UML)." Jurnal Sistem Informasi 8.1 (2019): 38-41.

[10] Mardiani, Eri, et al. 2019. Membuat Aplikasi Inventory dengan Java Netbeans, Mysql, dan iReport. Elex Media Komputindo.

[11] Yanto, Robi. 2016. Manajemen Basis Data Menggunakan MySQL. Deepublish. 